\title{
National Identity in the Context of Globalisation
}

\author{
Daniela Cârstea \\ University of Bucharest
}

Nationhood is not an a priori entity, if not a symbolic and communicative device around which people imagine themselves to be. Hence the concept of identity does not refer to a universal, fixed identity, but to a contingent, historically and culturally specific social construction. Fragmented, cross-cultural, multiple identities may be generated in the relationship between cultural identities and globalisation. Globalisation has increased the range of (re)sources available for identity construction, allowing for the production of hybrid identities in the context of a global society. The widespread "cut' n' mix" of cultural forms in the context of globalisation will be illustrated in the paper by the Bhutanese community. The ensuing changes will be analysed as leading not only to the fragmentation of the 'self' and the formation of multiple personal identities, closely followed by the fragmentation and differentiation of culture, but also to the destruction or undermining of the older bases of political and social identity. This process of fragmentation and multiplication is symptomatic of an erosion of national identity, a dissolving of it in the onslaught of globalisation.

Keywords: decentred, dislocation, disembedding, imperialism, subaltern

On an attempt at a fairly faithful rendition of the concept of nationhood, I would begin by asserting that the modern nation-state is a relatively recent invention and most of the human beings who have walked the earth did not participate in any kind of state nor identify with one. The nation-state and national identity as collective forms of organisation and identification are not naturally occurring phenomena, though we often think of them as such. Rather, they are particular, contingent historical-cultural formations.

The nation-state is a fundamentally political concept, which refers to an administrative apparatus deemed to have sovereignty over a specific space or territory within the nation-state system. National identity is a form of imaginative identification with that nation-state as expressed through symbols and discourses. Thus, nations are not only political formations but also systems of cultural representation - if we agree, with Stuart Hall, that national identity is only one kind of cultural identity, one form of imagining (The Question of Cultural Identity, 2002) - so that national identity is continually reproduced through discursive action. And, as some of the analysts argue, the nation-state as a political apparatus and a symbolic form has a temporal dimension, in that political structures endure and change, while the symbolic and discursive dimensions of national identity often narrate and create the idea of origins, continuity and tradition.

For Benedict Anderson, the nation is an "imagined community" and national identity a construction assembled through symbols and rituals in relation to territorial and administrative categories: 
It is imagined because the members of even the smallest nation will never know most of their fellow members, meet them, or even hear them, yet in the minds of each live the images of their communion. The nation is imagined as limited because even the largest of them, encompassing perhaps a billion living beings, has finite, if elastic boundaries, beyond which lie other nations. It is imagined as sovereign because the concept was born in an age in which Enlightenment and Revolution were destroying the legitimacy of the divinely ordered, hierarchical dynastic realm. Finally, it is imagined as a community because, regardless of the actual inequality and exploitation that may prevail in each, the nation is always conceived as a deep, horizontal comradeship. Ultimately, it is this fraternity that makes it possible, over the past two centuries, for so many millions of people, not so much to kill, as willingly to die for such limited imaginings. (Anderson, 1993, pp. 15-6)

The excerpt provides us with two fundamental ideas for the subsequent development of our argument, namely that nationhood is not an a priori entity, if not a symbolic and communicative device around which people imagine themselves to be one and identify with their neighbours, and that (national) identity is a limited imagining. This is to say that the concept of identity does not refer to a universal, fixed identity, but to a contingent, historically and culturally specific social construction. The inference is in concurrence with Stuart Hall's position on cultural identity, according to which, though we commonly assume that we have a 'true' self, an identity which we possess and which can become known to us and others, the latter is better understood as an ongoing description of ourselves marking a process of becoming (Hall, 2002, pp. 9-10). The idea that identity is plastic and open to continual change is referred to as anti-essentialism, whose main argument is that identities are contradictory, they crosscut or dislocate each other so that no single identity acts in an "overarching organising capacity" (ibidem). The situational description faithfully applies to the condition of the fractured, postmodern subject (who images his/her identity, of whatever brand).

According to Hall, the decentred or postmodern self involves the subject in shifting and fragmented identities so that persons are composed not of one but of several, very often contradictory, identities. Thus,

The subject assumes different identities at different times, identities which are not unified around a coherent 'self'. Within us are contradictory identities, pulling in different directions, so that our identifications are continually being shifted about. If we feel that we have a unified identity from birth to death, it is only because we construct a comforting story or 'narrative of the self' about ourselves. (Hall, 2002, p. 277).

Such fragmented, cross-cultural, multiple identities may and are generated in the relationship between cultural identities and globalisation. Globalisation has increased the range of sources and resources available for identity construction, allowing for the production of hybrid identities in the context of a global society where bounded societies and states are cut across by the circulation of other global cultural discourses. Indeed, the proliferation and diversification of contexts and sites of interaction prevents easy identification with a given, fixed identity so that the same person is able to "shift across subject positions according to circumstances." (Hall, 2006, p. 279)

But because reflections (in paradigms or taxonomies) of what reality is like can only be - as anthropologist Clifford Geertz argued - "logically equivalent, yet substantively quite different," (The Interpretation of Cultures, 1993, p. 210) and because the theoretical excursus stands in need of illustration and concrete extension, I will propose for analysis the suggestive reactions to the globalising forces of the Bhutanese people.

The widespread "cut' n' mix" (Hall's coinage) of cultural forms in the context of globalisation and the ensuing emergence of hybrid identities is amply illustrated by the Bhutanese community:

Already the impact of the West is apparent. Basketball has replaced archery as the national sport, thanks to the videotapes of NBA games that the king shipped to him from New York. Boogie Woogie, a game show sponsored by Colgate, now rivals the panoramic Himalayan 
vista for viewers' attention. Friends, Teletubbies, BBC and CNN entertain, inform and brief. A modern telecommunication system has been put in place and e-mail is replacing letter writing. [...] Children now make pilgrimages to monasteries offering prayers and lighting butter lamps while clad in Spice Girls T-shirts. Farmers sell apples, oranges, potatoes and cardamom to their Indian and Bangladeshi neighbours for foreign currency; and there are twenty-five privately-owned video stores in the capital city, Thimphu. (Hertz, 2011, p. 31)

These shifting and multiple identifications illustrate the multiplying global resources for the construction of identity because, as Hall suggested: "Multiple identities and the decentring of the social subject are grounded in the ability of individuals to avail themselves of several organisational options at the same time." (Hall, 2006, p. 52)

Thus, globalisation is the framework for the amplification and diversification of "sources of the self". In these circumstances, one possible response is to celebrate diversity, to pick and choose from among the array of cultural identities that a global culture makes accessible. Cosmopolitanism holds before us an image in which - as British David Miller ventured a prophecy - "we might explore our Celtic roots on Monday, spend Tuesday celebrating the Buddha's birthday in our neighbourhood temple, on Wednesday join in a Greenpeace demonstration against international whaling, and take part on Thursday in a critical discussion of British imperialism". (On Nationality, 2015, p. 29)

As a concept, globalisation refers both to the time-space compression of the world and the intensification of consciousness of the world as a whole, that is, the ever-increasing abundance of global connections and our understanding of them. "Modernity is a post-traditional order marked by change, innovation and dynamism whose institutions are said to be globalising because they allow for the separation of time and space, and the disembedding, or lifting out, of social relations developed in one locale and their re-embedding in different places." (Axtmann, 2016, p. 138)

This perspective highlights a loss of cultural diversity and the growth of 'sameness', attaching a negative evaluation to the process: "But the tentacles of global capitalism are far reaching, and no one can escape the one-kilowatt broadcast signals that now bounce between the thousands of satellite dishes that have over the past few years been appearing between the prayer flags and prayer wheels that dot the landscape". (140) So, technological innovations have created the conditions for a global system of symbolic interaction and exchange. These new communication media allow the dissemination of economically valuable data but, more importantly, make possible the transfer of mental images, exposing the recipients of these images to similar, "standardised ways of thinking and acting" (Axtmann, 2016, p. 123). In other words, the images transported have an impact on the culture and identity of the societies exposed to them. They could be seen as foreign cultural invaders diluting indigenous cultures and being instrumental in creating a global (Western) culture. So, even Bhutan, the last Shangri-La is being infiltrated. Unable to resist the spoils of the West, it admits Western influences.

This process of Western interrogation of the non-western 'other' was referred to as cultural imperialism, demanding cultural synchronisation, posed in terms of a loss of cultural autonomy and diversity, since central to the concept of cultural imperialism is the domination of one culture by another, the imposition of one national culture upon another with the media seen as central to the process, that is as carriers of cultural meanings which penetrate and dominate the cultures of subaltern nations.

It is unclear, though, whether globalisation is simply a process of homogenisation: "For a long time people didn't question the one-ideology, homogeneous world. Why should they? For many, life was good and getting better. [...] How could it be then that life had in so many ways never been better, yet I and so many around me seemed so troubled?" (Hertz, 2011, p. 78), since the forces of fragmentation and hybridity are equally as strong: "The steady erosion of government and politics is dangerous for all, regardless of political persuasion" (Hertz, 2011, p. 80).

In other words, the changes can also be analysed as leading not only to the fragmentation of the (modern) 'self' and the formation of multiple personal identities, closely followed by the fragmentation and differentiation of culture, but also to the destruction or undermining of the older bases of political and social 
identity and collective solidarities. This process of fragmentation and multiplication, which can be understood as the creation of a space that enables individuals to develop new loyalties and identities after the fracturing of the old 'narratives' (Lyotard, 2004,) is symptomatic of an erosion of national identity, a dissolving of it in the onslaught of globalisation, since the members of a community find it increasingly difficult to imagine themselves in a unitary way.

The outcome? Along this range of hybrid forms of identity, the production of nationalist resilience, of traditional, conservative nationalist identities: "We will not be rushed into an uncritical adoption of all things that are modern: we will draw on the experience of those who have trod the path of development before us, and undertake modernisation with caution, at a pace consistent with our capacity and needs. We therefore seek to preserve our culture, traditions, value systems and institutions. (emphasis added)" maintains the Bhutanese Minister of Planning. (The Kingdom of Bhutan Health System Review, 2017, p. 5) The attitude is obviously a conservative one, sustaining, as theoreticians would put it, "gradual continuity, cautious of, but not necessarily opposed to, change as long as it comes naturally." (Ştefănescu, 2012, p. 21)

In non-western countries, we are thus witnessing a playing out of the paradoxical dialectical tensions between 'modernisation and 'cultural' indigenisation, between the 'global' and the 'local', in short the dialectic of homogeneity and heterogeneity. How is it possible to ensure an "organic development", a slower-pace intake of change? How to be 'modern' without becoming Western? This situation, apparently paradoxical, self-contradictory, translates the tension that informs the search for preservation of an idiosyncratic collective identity and, altogether, a politics of cultural uniqueness that may be read as a response to the challenges of globalisation: "The path of development has been carefully managed so as to remain consistent with the country's integral system. [...] Yet, [...] e-mail is replacing letter-writing, despite the ten days of free mail service that Queen Tashi Dorji Wangno Wangchuk offered the Bhutanese to combat this very development." (The Kingdom of Bhutan Health System Review, 2017, p. 7)

In the past, one political tradition saw the state as a nation unified by a common culture: the state was both a political and a cultural unity (On Nationalism, 2012, p. 53). It is obvious that the Bhutanese share in such a conceptualisation of nationhood, which demands that cultural achievements be claimed for nations and culture be 'nationalised' and 'territorialised.' Maybe it is this 'nationalisation' of culture that found an expression in the expectation of uniqueness of identity, and thus the norm of particularism and localism: "[...] our culture, traditions, value systems and institutions". (The Kingdom of Bhutan Health System Review, 2017, p. 10)

In compliance with Hayden White's views in Metahistory on the discursive manner of structuring a conservative attitude, which conceives of irony as the fundamental trope of conservatism, I shall maintain that the nationalist identity in the age of globalisation is constituted in an ironical way, in full awareness of the rest of the world. In other words, "it plays opposites one against the other" (Metahistory, 2003, p. 18), on a paradoxical echafodage, since, although intent on and engrossed with endemicity, it does not aim at insulation from the world, but allows interactions with it. Since this process of identity formation and construal in the age of globalisation is embedded in this structure of interactivity, it is always precarious and fragile, hence always in peril of being overthrown and suffused in the stealthy infringement: "We stand today at a critical juncture. If we do nothing, if we do not challenge the Silent Take-over, [...] all is lost." - a warning voiced by Noreena Hertz. (The Silent Take-Over, 2011, p. 73)

In an attempt at self-reflexivity - which is de bon ton in postmodern times - we could undertake an evaluation of the canons of appraisal employed in identifying and foregrounding tropological structures of conservative attitude, arguing that the production of meaning does not ensure consumption of that meaning as the encoder might have intended, since messages, constructed as a sign system with multi-accentuated components, are polysemic. (Jakobson, 1999, pp. 14-6) They carry multiple meanings and can be interpreted in different ways. That is not to say that all the meanings are equal among themselves. Rather, the text will be "structured in dominance" (Jakobson, 1999, p. 29) leading to a "preferred meaning", that is the one the text guides us to.

Work within the tradition of hermeneutics and literary reception studies further challenges the idea that there is one textual meaning associated with authorial intent and that the texts are able to elicit meanings created by readers. For Gadamer, the relationship between the text and the reader was an interactive one, 
in which the reader approached the text with certain expectations and anticipations, which were modified in the course of reading, to be replaced by new "projections". (Truth and Method, 2004) Thus, understanding is always from the position and point of view of the person who understands, and involves not merely reproduction of secure textual meaning, but its production by the reader. The text may guide the reader, but it cannot fix meanings that are the outcome of the oscillations between the text and the imagination of the reader. My own conceiving, or rather reconceiving of the text is, as argued, that we are faced with an example of a conservative attitude displayed in reaction to fragmentation, a fracturing of national identity (Bhutanese) in the process of globalisation.

All in all, the conclusion would be that globalisation is a contradictory process. Spurred by the increase in the global access to economic and political processes, as well as by the global flow of information, communication and technology, globalisation is fostering manifestations of a global consciousness, which conceives of the world as one place. Despite ( or rather because of) these processes, there are also pressures to be detected towards the assertion of regional autonomy, localism and local identities - as I argued in the case of Bhutan. In other words, homogeneity, as much as heterogeneity and fragmentation are constitutive of the process of globalisation.

Of course, questions arise: will cultural globalisation result in global cultural homogeneity? Will localisms be swept away by the forces of Western cultural imperialism? Or will cultural globalisation result in generating and upholding heterogeneity as a feature as much inherent in its logic as homogenisation?

The search of identity within a global world may express itself politically in the formation of global consciousness that perceives the world as one place and sees individuals as part of an all-encompassing humankind. But it may also manifest itself in a self-reflexive consciousness - as attempts were being made in the case Bhutan - a civilisationally specific one. In any case, one thing there can be no doubt about is that the nation is still a concept in which community is "imagined" (Anderson), even though these processes of globalisation compel us to reconceptualise the social (and political) world in which we live.

\section{REFERENCES}

Anderson, B. (1993). Imagined Communities: Reflections on the Origins and Spread of Nationalism. London: Verso.

Axtmann, R. (2016). Liberal Democracy into the Twenty-first Century. Manchester: Manchester University Press.

Gadamer, H-G. (n.d.) Truth and Method. Retrieved from https://mvlindsey.files.wordpress.com/2015/08/truth-and-method-gadamer-2004.pdf

Geertz, C. (1993). The Interpretation of Cultures. New York: Basic Books, Inc.

Hall, S. (2002). The Question of Cultural Identity. In S. Hall, D. Held, \& T. McGrew (Eds.), Modernity and its Futures. Cambridge: Polity Press.

Hall, S. (2006). Who Needs Identity? In S. Hall \& P. Du Gay (Eds.), Questions of Cultural Identity. London: Sage.

Health Systems in Transition. (2017). The Kingdom of Bhutan Health System Review, 7(2).

Hertz, N. (2011). The Silent take-over. Global Capitalism and the Death of Democracy. London: William Heinemann.

Hutchinson, J., \& Smith, A. (Eds). (2004). On Nationalism. Oxford; New York: Oxford University Press.

Jakobson, R. (1999). On Language, edited by L. Waugh \& M. Monville-Bruston. Cambridge, Mass.:

Harvard University Press.

Lyotard, J-F. (2004). The Postmodern Condition (4th edition). University of Minnesota Press.

Miller, D. (2015). On Nationality. Oxford: Clarendon Press.

Ştefãnescu, B. (2012). Postcommunism/ Postcolonialism: Siblings of Subalternity. Bucharest Publishing House.

White, H. (2003). Metahistory. Johns Hopkins University Press. 